Article

\title{
Circular Economy, International Cooperation, and Solid Waste Management: A Development Project in La Paz (Bolivia)
}

\author{
Navarro Ferronato ${ }^{1, *(\mathbb{D}}$, Rodolfo Pasinetti ${ }^{2}$, Daysi Valencia Vargas ${ }^{2}$, Iris Jabneel Calle Mendoza ${ }^{2}$, \\ Edith Gabriela Guisbert Lizarazu ${ }^{3}$, Marcelo Antonio Gorritty Portillo ${ }^{3}$, Fabio Conti ${ }^{1}\left(\mathbb{C}\right.$ and Vincenzo Torretta ${ }^{1} \mathbb{C}$ \\ 1 Department of Theoretical and Applied Sciences, University of Insubria, 21100 Varese, Italy; \\ fabio.conti@uninsubria.it (F.C.); vincenzo.torretta@uninsubria.it (V.T.) \\ 2 COOPI-Cooperazione Internazionale, Bolivian Office, La Paz 3520, Bolivia; coord.bolivia@coopi.org (R.P.); \\ pm.recicla.bolivia@coopi.org (D.V.V.); tecnico.recicla.bolivia@coopi.org (I.J.C.M.) \\ 3 IIDEPROQ, Universidad Mayor de San Andrés (UMSA), La Paz 3520, Bolivia; \\ gabriela_glizarazu@yahoo.es (E.G.G.L.); mgorritty@gmail.com (M.A.G.P.) \\ * Correspondence: navarro.ferronato@uninsubria.it
}

Citation: Ferronato, N.; Pasinetti, R.; Valencia Vargas, D.; Calle Mendoza, I.J.; Guisbert Lizarazu, E.G.; Gorritty Portillo, M.A.; Conti, F.; Torretta, V. Circular Economy, International Cooperation, and Solid Waste Management: A Development Project in La Paz (Bolivia). Sustainability 2022, 14, 1412. https://doi.org/ $10.3390 /$ su14031412

Academic Editor: Luis Jesús Belmonte-Ureña

Received: 20 December 2021

Accepted: 21 January 2022

Published: 26 January 2022

Publisher's Note: MDPI stays neutral with regard to jurisdictional claims in published maps and institutional affiliations.

Copyright: (C) 2022 by the authors. Licensee MDPI, Basel, Switzerland. This article is an open access article distributed under the terms and conditions of the Creative Commons Attribution (CC BY) license (https:// creativecommons.org/licenses/by/ $4.0 /)$.

\begin{abstract}
This paper introduces the preliminary results of a development project focused on waste recycling and recovery in La Paz (Bolivia). The aim is to share best practices and to present real-world challenges when implementing appropriate waste management systems in developing countries. Environmental pollution, social inequality, lack of resources, and economic discrepancies are challenges still present in the 21st century, and a global call-for-action is needed to support sustainable development. The project "LaPazRecicla", financed by the Italian Agency for Development Cooperation, provides perspectives that are potentially useful for policy-makers, waste management practitioners, and circular economy visionaries. The article aims to present the effective contribution of the practical actions to the local municipality, and to introduce the reason for why theoretical methods were employed to support the project. The outcomes provided two main indications: on one hand, cooperation among interdisciplinary actors and financial support can give the chance of improvement, suggesting international donors should continue in this direction; on the other, political instability, lack of local technical knowledge, and the absence of planning for a long-term period makes these actions unsuitable for tangible change. Global reflections are required in order to measure the potential benefits of small-scale projects, evaluating the time needed to move towards a sustainable future in low-income countries.
\end{abstract}

Keywords: developing countries; international cooperation; LCA; recycling; resource recovery; solid waste; sustainable development; waste to energy

\section{Introduction}

Developing countries suffer many issues in solid waste management (SWM). The low coverage of the collection services and the poor conditions of disposal sites is common, representing the main problem [1,2]. At an international level, within the SWM, a focus on public health and climate change is imperative. It has been estimated that uncontrolled disposal will continue to increase until 2028, reaching almost 730 million $t$ of waste per year [3]. Therefore, appropriate waste collection and disposal should be prioritised to avoid the spread of disease vectors from uncollected waste and landfill gas emissions [4].

High discrepancies in SWM can be found at the international level regarding the different income levels [5]. The SWM in low-income countries is generally characterised by high landfilling rates; the opposite is true of countries with high gross domestic product (GDP) levels [6]. However, research impacts for improving SWM are more frequent in developed countries than in developing countries where economy, technology, and society factors are not effective [7]. This means that low-income countries have a low bar for 
improvement; however, to better address climate change, developing countries need to establish cooperation while optimising the allocation of climate change resources [8,9].

International cooperation can play an important role in the support of developing countries' improvement of solid waste collection and disposal. High-income countries can aid low-middle income regions in research and development to reduce open waste dumping and burning. In particular, integrated thinking and appropriate projects can help with achieving sustainable development [10]. For example, the Japan International Cooperation Agency and the Indonesian Government have implemented a solid waste separation and collection project in Balikpapan City, Indonesia [11]. In Jordan, an attempt to solve open waste dumping and the lack of waste collection has been made in recent years with international donors to enable municipalities to meet the growing demand in basic SWM services [12]. UN-Habitat implemented a project in Managua (Nicaragua) to strengthen capacities for SWM to guide the evolution of the system in forthcoming years [13].

Therefore, international cooperation is a common practice to support appropriate waste collection and disposal. However, projects can face cooperation problems between international, national, and local actors due to different levels of commitment [14]. Therefore, precautions should be considered to implement appropriate, sustainable, and longterm-result projects, while research, development, and successful case studies should be introduced by the scientific community in order to support this global action.

This article offers a contribution to the spreading of knowledge about SWM in developing countries and aims to present approaches and preliminary outcomes carried out within an international cooperative project implemented in Bolivia. The reason behind the article is to show the positive effects and real-world challenges when implementing actions for improving SWM in low-middle income regions within an international cooperative framework. The hypothesis is that this research and case study can provide effective ideas and examples to international cooperative operators, international lenders, SWM practitioners, and policy makers to start practical actions towards sustainable development.

The project implemented in Bolivia, financed by the Italian Cooperation, and called "LaPazRecicla", aims to introduce a circular economy model within the municipality of La Paz. In a circular economy, the role of waste management is to promote the preservation of material of value in the life cycle through waste recycling and recovery [15]. The actions implemented within the project and presented in this article would provide technical assistance and infrastructures to improve and move the current waste recycling system of La Paz towards a more circular system. Both waste recycling and recovery are involved, for municipal solid waste (MSW) and construction and demolition waste (CDW) in particular.

Creating a viable cooperative movement in the SWM sector requires access to materials, markets, and business development support [16]. In addition, various factors should be taken into account, such as organisational capacity, technology systems and facilities, law enforcement, behaviour and culture, collaboration, and synergy, among others [17]. The project presented in this paper introduces some of these variables, giving an example that can be replicated and scaled in other contexts at the international level. That is the novelty of this scientific contribution and the positive impact that it can give to the international scientific literature, guiding research towards a sustainable future.

\section{Methods}

\subsection{Overview of the Project}

The project presented in this article is the result of a research activity conducted from 2016 to 2019, the cooperation among various actors involved in SWM, and the international cooperation between Italy and Bolivia [18]. The development project is focused on the MSW and CDW management system of La Paz. In particular, the objective is to support the improvement of the recycling system and the inclusion of waste generators in MSW and CDW selective collection policies. 
The article explores (1) the practical actions implemented in La Paz, and (2) the theoretical methods employed to support the activities. In particular, the practical actions are introduced and described which includes three main activities:

a. The construction of small-scale recycling plants to support the selective collection and recycling of MSW and CDW;

b. The organisation of MSW recycling campaigns, as well as courses and seminars to involve students and citizens, and to improve local technical capacities in SWM;

c. Laboratory analysis and testing of non-recyclable waste combustion for energy recovery to assess its potentialities.

In parallel, three theoretical approaches were employed for evaluating local environmental, social, and economic opportunities in recycling:

1. Life cycle assessment (LCA) for assessing environmental performances of the SWM system;

2. Material flow analysis (MFA) and assessment of future CDW recycling scenarios;

3. Questionnaire surveys for measuring the involvement of the population in selective collection and recycling activities.

The article aims to present the results in terms of effective contributions to the local municipality with which the practical actions were involved, and to introduce and explain the reason for why such theoretical methods were employed. Pros and cons, opportunities, and challenges, as well as replicability and future developments of the actions, are described to boost the sustainable development and appropriate management of solid waste.

\subsection{SWM System of La Paz}

La Paz consists of about 950,000 inhabitants, and it is one of the most important cities of Bolivia, which is classified by the World Bank as a low-middle income country. The MSW management system includes a formal and an informal one. The informal recycling system is active in the city, with about $40 \mathrm{t}$ of waste recycled per day [19] and with the participation of more than $70 \%$ of the population that commonly implement selective collection [20]. The waste formally collected at municipal level amounts to about $649 \mathrm{t}$ per day, for a total of about 237,000 t of waste generated per year. Therefore, the amount of waste produced at the municipal level, considering the formal and informal collection systems, as well as the uncollected waste, can be as much as about $700 \mathrm{t}$ per day.

The organic fraction is the one generated mostly at the municipal level (more than $50 \%$ ), followed by recyclable materials (about 25\%) and mixed non-recyclable waste, as is typical of the waste characterisation of a developing city [21,22]. The formal MSW management system includes a sanitary landfill and a material recycling facility (MRF) with the capacity of about $1000 \mathrm{t}$ of waste per year, and a composting plant with the capacity of about $30 \mathrm{t}$ per day. Therefore, the MSW collection system involves mixed and selective street containers and transportation via compactor trucks. It can be estimated that about $95 \%$ to $99 \%$ of the MSW formally collected at the municipal level is disposed of in a final disposal site, while the informal recycling system can potentially contribute to improving the municipal recycling rate to about $8 \%$.

The CDW management system implemented at the municipal level is totally informal. Before 2021, no formal collection and treatment systems were available in Bolivia, as is common in developing countries $[23,24]$. The amount of CDW generated in La Paz is estimated by secondary data. At the municipal level, potentially more than $120,000 \mathrm{t}$ of CDW per year can be generated. Generally, the waste generated is transported by open lorries, and the waste is disposed of in rivers or open lands. However, the data used by the local decision-makers are not supported by reliable analysis, while the informal system is not monitored.

\section{3. "LaPazRecicla" Project}

The project described in this paper is called "LaPazRecicla. Integrated solid waste management in the municipality of La Paz, Bolivia. New technologies for fostering the circular 
economy". It is a project funded by the Italian Agency for Development Cooperation (AICS) and led by the Italian NGO COOPI, in collaboration with the Faculty of Engineering of the Universidad Mayor de San Andrés (UMSA), the Department of Theoretical and Applied Sciences of the University of Insubria (Varese, Italy). and with the local counterpart, the Autonomous Municipal Government of La Paz (GAMLP). LaPazRecicla started with the objective to improve city sustainability through the introduction of inclusive, innovative, and appropriate SWM systems, encouraging the recovery of materials in order to activate a circular economy within the framework of the Sustainable Development Goals (SDGs) of the United Nations (UN).

The project involves the population and various social, economic, and governmental target groups to improve the local SWM system, with a focus on inorganic MSW (plastics, glass, and cardboard) and CDW, which currently represent an important environmental threat for the city. The outcomes of the project would be:

1. The improvement of the circular economy of solid waste by, on one hand, implementing and investigating new technologies that allow the recovery of non-recyclable waste into energy, and on the other, the implementation of treatment plants;

2. The reduction of the negative environmental impacts caused by uncontrolled disposal of CDW. The project will support the development of patterns for proper waste management, for setting up a plant for its selection, and for recycling;

3. The enhancement of the efficiency and effectiveness of the MSW recycling process by introducing equipment for its valorisation once they have been selected, involving the population so as to increase the participation in the MSW selective collection, and involving the youngest by supporting the organisation of recycling campaigns;

4. The reinforcement and improvement of local technical skills related to innovative methods for the recovery and recycling of waste by supporting scientific research and the exchange of experiences with other countries in Europe and Latin America.

The project started in 2019 and will conclude by the end of 2022. This three-year project would be replicated in other areas of Bolivia and the aim of this scientific article is to make it replicable in other contexts of the world.

\subsection{Research and Developments}

The actions and methods implemented within the LaPazRecicla project are summarised in Table 1. The objective of each activity, the tools employed, and the roles of the actors involved within the project are introduced.

\subsubsection{Practical Actions}

The most important on-field action is the implementation of waste treatment systems. Three treatment plants for MSW, and one for CDW, were implemented, together with one machine for converting unrecyclable paper waste into materials for energy recovery.

The first CDW sorting and recycling system of Bolivia has been built in La Paz, thanks to this project. A breaking and sieving system has been built in order to generate two material flows: a small-size material, and a medium-size material. Part of these flows are used for building bricks from recyclable materials, partly substituting the virgin ones, and generating the first example of circular CDW management in Bolivia. 
Table 1. Description of the methods and actions implemented within the project.

\begin{tabular}{|c|c|c|c|}
\hline Method/Action & Objectives & Tools & Actors Involved and Roles \\
\hline \multicolumn{4}{|c|}{ Practical Actions } \\
\hline Construction of pilot plants & $\begin{array}{l}\text { To improve the quality of the } \\
\text { secondary raw materials for } \\
\text { recycling (inorganic MSW and } \\
\text { CDW); to evaluate the } \\
\text { feasibility of improved and } \\
\text { public recycling actions. }\end{array}$ & $\begin{array}{l}\text { Implementation } \\
\text { of small-scale } \\
\text { machineries }\end{array}$ & $\begin{array}{l}\text { The Italian NGO manages the } \\
\text { budget and coordinates the } \\
\text { actions; private companies } \\
\text { build the machineries and } \\
\text { make them operate; the } \\
\text { municipal government of La } \\
\text { Paz has the responsibility to } \\
\text { manage the treatment plants } \\
\text { once implemented; the } \\
\text { universities supervise the } \\
\text { actions and support the } \\
\text { activity with pilot tests and } \\
\text { technical courses. }\end{array}$ \\
\hline Social involvement & $\begin{array}{l}\text { To inform the citizens about } \\
\text { the selective collection plans } \\
\text { implemented by the } \\
\text { municipality; to collect } \\
\text { information about social } \\
\text { behaviour in recycling; to } \\
\text { improve local awareness and } \\
\text { knowledge in recycling needs. }\end{array}$ & $\begin{array}{l}\text { Public campaigns, webinars, } \\
\text { technical courses, online } \\
\text { activities, and workshops. }\end{array}$ & $\begin{array}{l}\text { The NGO organises the events } \\
\text { once the local municipality } \\
\text { approves and supports them; } \\
\text { the local citizens and students } \\
\text { attend and participate in the } \\
\text { online events and in-presence } \\
\text { activities; universities provide } \\
\text { technical knowledge and } \\
\text { organise the courses. }\end{array}$ \\
\hline Laboratory analysis & $\begin{array}{l}\text { To evaluate environmental } \\
\text { and technical benefits of } \\
\text { waste-to-energy } \\
\text { options (SRF and } \\
\text { waste-based briquettes). }\end{array}$ & $\begin{array}{l}\text { Sensors, } \\
\text { laboratory tests, } \\
\text { and tools }\end{array}$ & $\begin{array}{l}\text { Universities implement the } \\
\text { laboratory tests once the local } \\
\text { municipality provides the } \\
\text { waste and rejects; the NGO } \\
\text { manages the budget and buys } \\
\text { the tools required for } \\
\text { the analysis. }\end{array}$ \\
\hline
\end{tabular}

\section{Theoretical Methods}

To evaluate environmental

benefits of the action and to

quantify the potential

environmental impacts generated by the SWM system.

To estimate the amount of CDW generated at the municipal level and to

Scenario's analysis quantify the economic benefits that the use of recyclable aggregates can provide to the SWM system.

The NGO supervises the activity; the local municipality provides the available primary data; the university is responsible for the activity.

The NGO supervises the activity, while the municipal government provides the primary or secondary data available locally; the universities have the role to implement the research and to conduct the analysis.

The NGO and the municipality organize the campaigns and support the activities to collect the

To evaluate the formal and informal selective collection Social surveys behaviour of the citizens and to identify the recycler profile of local citizens.
Questionnaires information; the universities organise and collect the data as well as implement the statistical analysis; the citizens are involved through online and local campaigns. 
For improving the MSW recycling systems, three machines were introduced. All were built locally, with local know-how and industrial capacity. The first machine is a glass shredding system. It has been implemented in order to increase the economic value of glass waste: if shredded and selected in homogenous size and quality, it can raise the economic value of glass waste by three to four times in the Bolivian market. Secondly, a plastic-waste shredding and cleaning system have been built. The objective is to treat the plastic waste (PELD) so as to increase its economic value and recyclability. Typically, in Bolivia, PELD is used for packing milk, yogurt, and juice. Plastic, most of the time, is dirty and has high sugar contents, making it not always reliable for recycling. The machinery cleans the plastic waste and gives it a uniform size that makes it attractive for the local recycling market. Finally, a paper-waste shredding system is implemented. It will pre-treat the waste in order to make it easier to be converted to a fuel-like material. In particular, the shredded material is densified in a briquetting machine.

A briquetting machine has been located within the local MRF in order to convert the non-recyclable paper and cardboard waste into waste-based briquettes. The shredded cardboard, together with sawdust, is converted into high-density products that can be used for generating energy for cooking and heating in industries and rural areas. The application of the machine can provide another use to a waste that is currently disposed of in the local sanitary landfill. All these recycling facilities are on a pilot scale, in order to evaluate the feasibility of the action and the developments of the local recycling market.

The densified waste produced by the briquetting machine is analysed within the laboratories available in the local university. Laboratory tests were conducted for evaluating the characteristics both of the cellulosic and biomass-based briquettes, and of the nonrecyclable plastic and cellulosic waste that cannot be used for household purposes (i.e., cooking and heating), but that can be, rather, employed for energy production in industries (i.e., cement kilns). In particular, the characteristics of a solid recovered fuel (SRF) from material rejects of the MRF (i.e., plastics and cellulosic fractions) were analysed, while the potentialities of briquette combustion were assessed through a water boiling test and emissions analysis.

In parallel, recycling campaigns were arranged, together with online webinars and technical courses. The campaigns were structured both online, due to the COVID-19 pandemic, and in-presence within local fairs organised by the local government on the weekend. During the campaigns, children were involved with "awareness games", while adults were educated with information materials (i.e., flyers and triptychs), and their opinions were collected through a questionnaire survey. In addition, online courses and seminars were set up with international invited speakers and local stakeholders. The objective was to disseminate the results of the project and to inform local citizens and experts in the field of SWM about current advances in waste treatment technologies and management.

\subsubsection{Theoretical Approaches}

The objective of the project is to reduce the environmental impacts generated by the SWM of La Paz. For estimating such an improvement, the life cycle assessment (LCA) approach has been employed. The potential environmental impacts generated by the local MSW management and CDW mismanagement were calculated with the aid of the WRATE v.4 software, and some considerations were carried out in the function of the recycling rates achievable by the system, the transportation distances, and the selective collection implemented at the city level. The results were compared with a final LCA, considering the improvements carried out because of the project.

On the other hand, a material flow analysis (MFA) and a scenarios analysis have been carried out in order to estimate the amount of CDW potentially generated at the municipal level and the future improvements that recycling actions might contribute to the municipal level in terms of financial sustainability. The analysis has been conducted with secondary data due to the lack of on-site information availability. 
Finally, statistical data analysis of a questionnaire survey was conducted in order to verify the characteristics of the recycler profile at the municipal level, and the behaviour of the local population in MSW recycling and source segregation. Questionnaires were submitted to the citizens during the recycling campaigns and data were evaluated through the RStudio ${ }^{\circledR}$ software (Version 1.1.463 - (C) 2009-2018 RStudio, Inc.). Questionnaires contained six groups of questions, for a total of nine queries on the topic of waste and seven to obtain data on the characteristics of the participants. The forms were shared through social networks and messages and were developed on the free online platform "Google Forms". The online survey was carried out during December 2020 and only within the boundaries of the metropolitan area of La Paz. The statistical significance of the answers was measured through a confidence interval at 95\% confidence level. In total, 998 citizens participated in the online survey.

\subsection{Analysis of the Results}

This paper describes the main characteristics of the practical action introduced, and the results obtained, by the project. Quantitative results are presented, particularly in relation to the waste flows, while the roles of the actors involved and the outcomes of the analysis are introduced. Therefore, qualitative and quantitative descriptions of the pilot actions are provided, as well as of the field analysis and the results of the theoretical methods. Finally, the future developments are presented, placing emphasis on the chances for the replicability of the approaches. The pros and cons of each practical and theoretical action are also underlined. Challenges are finally discussed, in order to present the main barriers that might arise in an international cooperative project implemented within a low-middle income economy.

\section{Results}

\subsection{Treatment Plants}

\subsubsection{CDW Sorting and Recycling}

The CDW treatment and recycling system has been built in April 2021. It has been developed using Bolivian technologies and it has been operated by a local private company. The MRF can, potentially, treat about $60 \mathrm{t}$ of CDW per day, covering about less than $10 \%$ of the capacity required by the municipality. Figure 1 reports the photos of the treatment plant implemented in La Paz, the material inflow, and the final products obtained.

The treatment plant generates two flows of recyclable aggregates: a gross one and a fine one. The gross aggregates fraction has a diameter of about 1.3 to $2.5 \mathrm{~cm}$, with an average density of $1185 \mathrm{~kg} \mathrm{~m}^{-3}$ and an absorption rate of $10.1 \%$. The fine fraction has a size of about 1 to $1.3 \mathrm{~cm}$ with a density of about $1247 \mathrm{~kg} \mathrm{~m}^{-3}$ and an absorption rate of $13.2 \%$. The estimation of the amounts of waste rejected by the system is not yet available, nor is the percentage of waste that has been used for recycling. However, investigation and market analysis will be conducted in the coming months in order to assess the economic and environmental benefits of the system. Indeed, the treatment plant will be improved in order to better define the market of the products, the type of waste inflow into the system, and the time of operation required, among other factors that can be assessed due to the small-scale nature of the recycling plant.

\subsubsection{MSW Pre-Treatment for Recycling}

Three treatment plants were built and located within the MRF of La Paz. The first treatment plant is the shredding and washing system of recyclable plastics. Figure 2 reports the description of the treatment plant and the construction of the machine. The plant can generate plastic flakes that can be sold to the Bolivian recycling markets. The treatment system can play an important role in improving the recyclability of the waste generated at schools. However, during the current period, the COVID-19 pandemic does not allow children to be present daily at school, reducing the amount of PELD usually generated 
and selectively collected, which amounted to about $1 \mathrm{t}$ per day (Monday-Friday) before the pandemic.

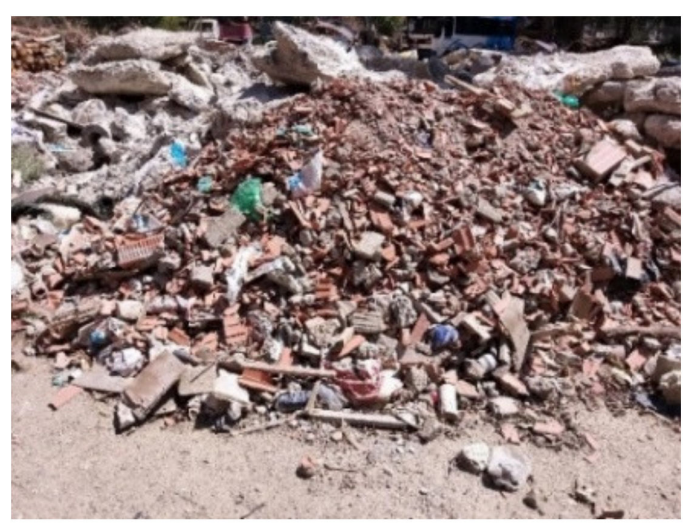

(a)

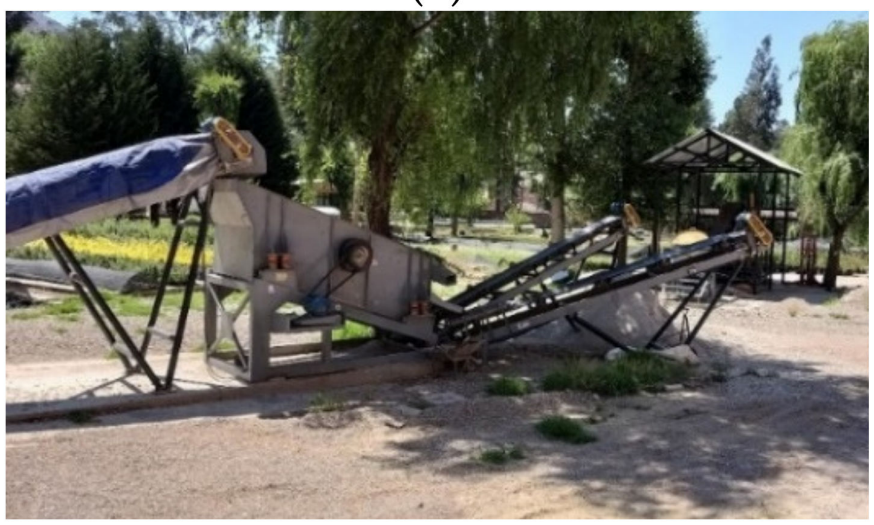

(c)

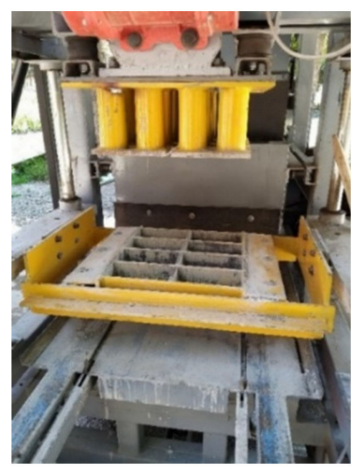

(e)

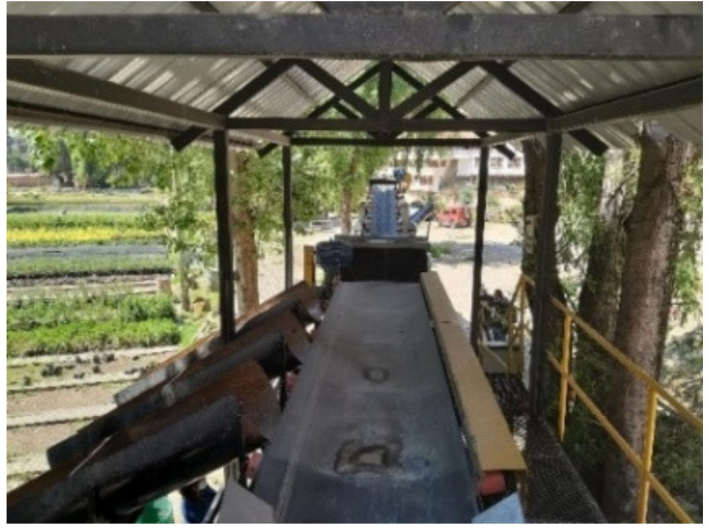

(b)

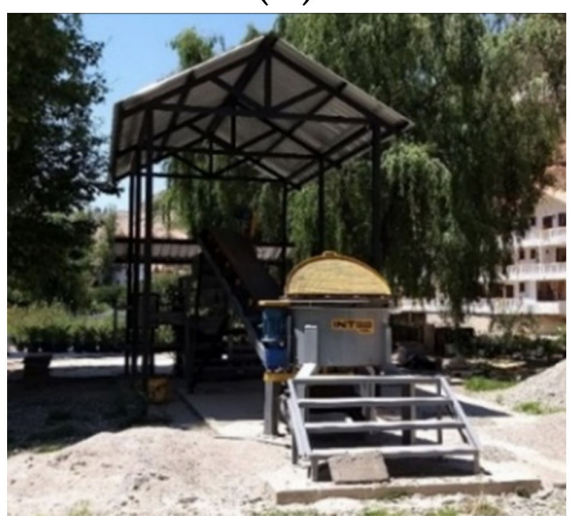

(d)

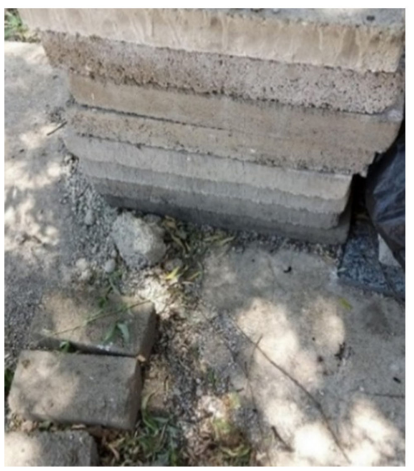

(f)

Figure 1. CDW treatment and recycling plant: (a) type of waste inflow to the treatment plant; (b) area dedicated to the manual selection; (c) final sieving system and generation of secondary raw materials; (d) recycling plant for the production of bricks made of recyclable aggregates; (e) moulds used for bricks production; (f) example of bricks and blocks produced with the use of recyclable aggregates obtained from the selection plant. 


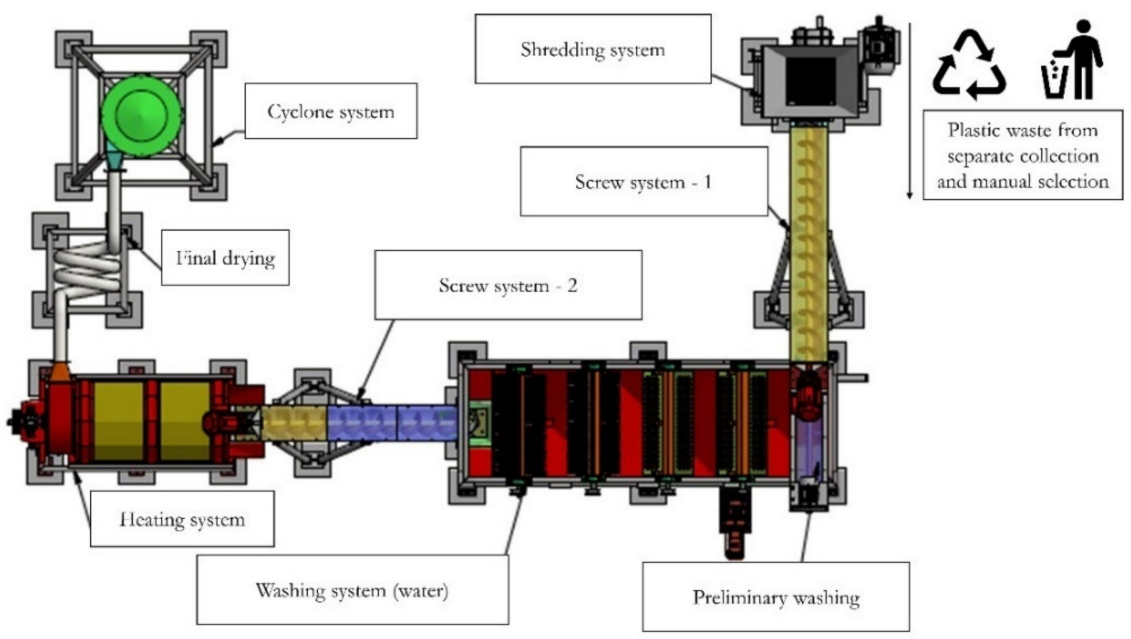

(a)

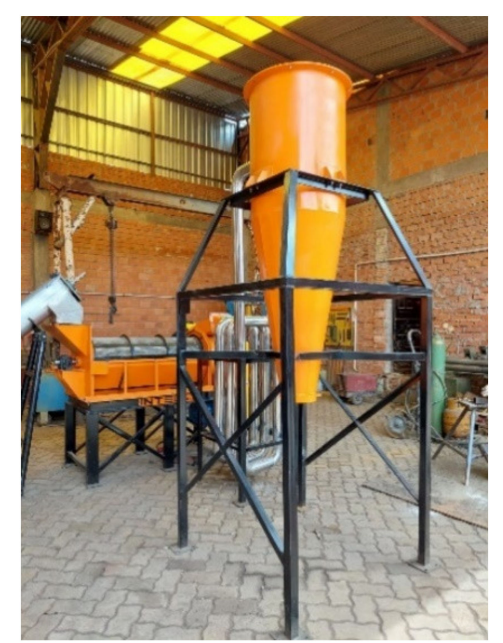

(b)

Figure 2. Plastic waste recycling plant implemented in La Paz: (a) definition of the system and characteristics of the plant; (b) treatment plant (cyclone and heating system) constructed in La Paz.

The other two treatment plants are the glass and cardboard shredding systems. Figure 3 reports the machines under operation. The secondary raw materials obtained is glass pieces with sizes smaller than $3 \mathrm{~cm}$. The uniform dimension of the waste improves its market value, increasing its price four-fold. The next step is to provide the recyclable glass with uniform colours, again increasing its market value. The paper shredding system has a similar capacity to the glass shredding process. The objective is to employ the shredded material in the briquetting machine in order to produce waste-based briquettes that can be employed for heating and cooking in rural areas. Therefore, the cellulosic materials treated are mainly composed of non-recyclable waste fractions, although the briquetting process can be used also for improving paper-waste management and transportability.

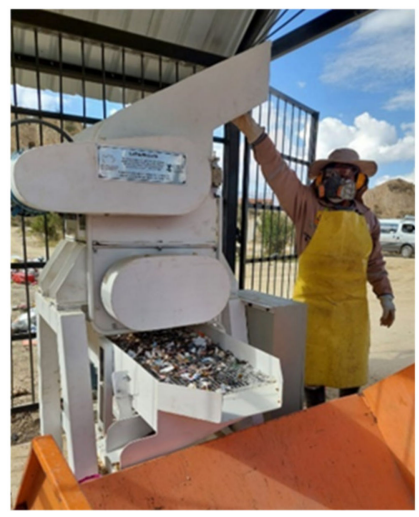

(a)

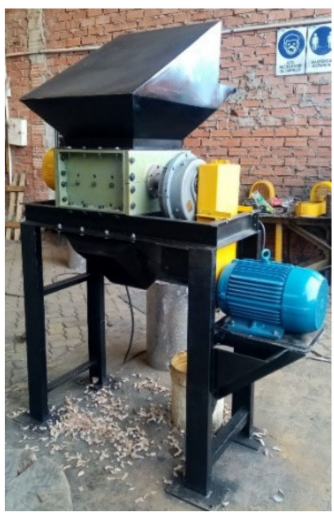

(b)

Figure 3. MSW treatment plants implemented by the "LaPazRecicla" project. (a) Glass shredding system located in the municipal waste selection plant; (b) paper and cardboard waste shredding machine built in a Bolivian workshop.

\subsubsection{Waste Briquetting}

Densification technologies are used for the valorisation of waste for producing solid fuels in rural and peri-urban areas [25] with the aid of high-pressure briquetting technologies [26]. Within the project LaPazRecicla, a briquetting machine was implemented in order to convert cellulosic waste fractions into potential fuels for the Andean rural areas. In Figure 4, an example of waste-based briquettes produced by the densification 
process is reported, as well as the co-combustion of the same briquettes into an improved cookstove at laboratory scale. A second-hand RB 30 SV briquetting machine, using German technology, built in 2008, and obtained by the project with less than 10 working hours, has been located at the laboratories of the University of San Andrés. This machine was unused and unemployed by a local foundation and the project gave it a second life.

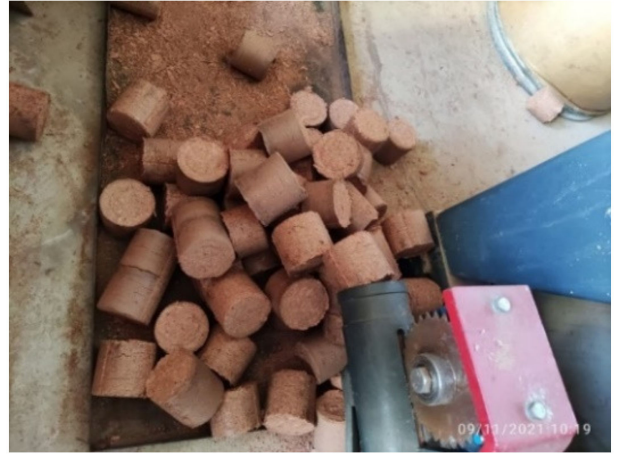

(a)

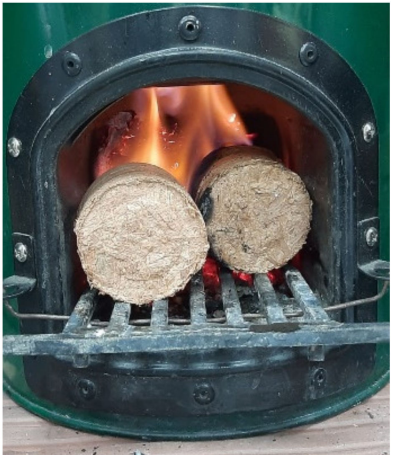

(b)

Figure 4. Waste-based briquettes produced in La Paz. (a) Production of cardboard waste and biomass-based briquettes; (b) experimental analysis of briquettes combustion at laboratory scale.

With a power of $5.5 \mathrm{~kW}(15 \mathrm{~A})$ and a weight of $0.5 \mathrm{t}$, the briquetting machine allows the treatment of about $30-50 \mathrm{~kg} \mathrm{~h}^{-1}$ of cellulosic or biomass waste. The briquettes produced are $0.5-\mathrm{cm}$ thick and 3-cm long. The density is variable, from 800 to $1200 \mathrm{~kg} \mathrm{~m}^{-3}$, depending on the material treated, about two times the fuelwood density. The treatment plant can work for about $1.5 \mathrm{~h}$; after that, it should remain without operation for about $3 \mathrm{~h}$ in order to cool the hydraulic system. Therefore, the machine can work about $4 \mathrm{~h}$ per day, with a maximum daily production of about $200 \mathrm{~kg}$. The briquettes produced by the system are then analysed at a laboratory scale in order to compare them with fuelwood and to evaluate the best mix of waste that can be introduced for producing the most performable briquettes for cooking and heating.

\subsection{Laboratory Analysis-Waste to Energy Options}

\subsubsection{SRF Analysis and Characterisation}

The first laboratory analysis conducted within the project regards the evaluation of the potentialities of the non-recyclable waste as SRF. To date, in Bolivia, SRF is not considered within the national regulation, and it is not used as an alternative fuel. Therefore, the aim of the research is to provide the technical capacities and the first results of local potentialities for the exploitation of SRF in cement kilns.

The waste has been collected from the municipal MRF. An example of the sampling procedure is reported in Figure 5. Only non-recyclable plastics and paper waste was involved in laboratory tests since the general objective was to maximise material recovery. The international standards related to EN 15359:2011 for the classification of the SRF were employed. Then, the mix of materials most attractive for the cement industry were investigated. It has been estimated that the fossil fuels (i.e., methane) employed by the Bolivian cement industry will be potentially consumed before the end of 2035 . Therefore, alternative fuels should be found in the short term, while cement kilns are expected to be the most relevant industry that can receive and consume SRF. The low calorific value (LCV), chlorine, and mercury concentration were evaluated according to the norm. 


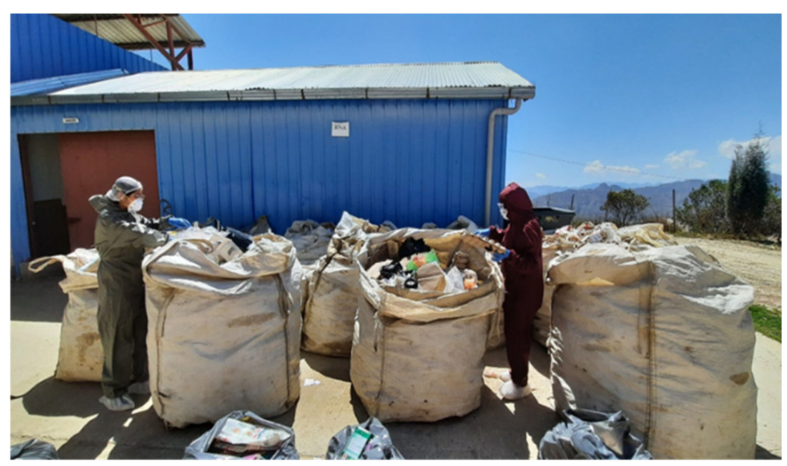

(a)

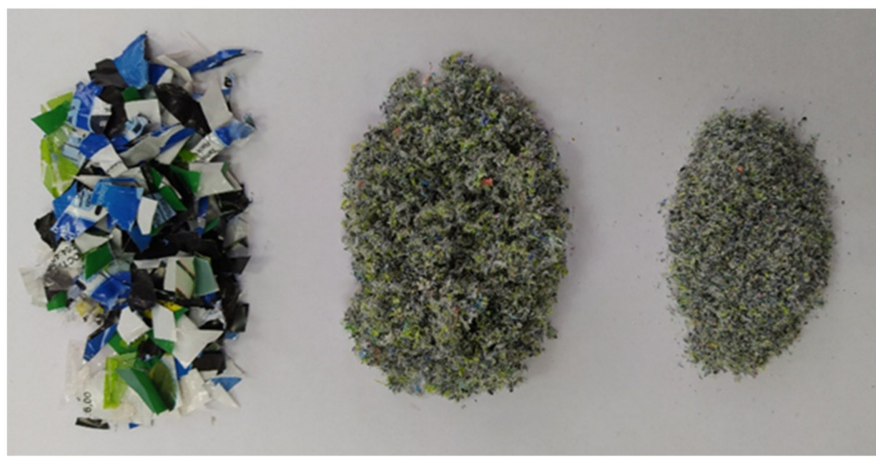

(b)

Figure 5. Sampling procedure of the rejected materials: (a) rejects collection from the MRF of La Paz; (b) shredded non-recyclable plastics for laboratory testing.

The findings of the laboratory analysis allow for demonstrating that the rejects produced in the MRF of La Paz can be classified as fuel if correctly managed and analysed. On average, two blends can be identified: the first, maximising the cellulosic content mixed with plastics, the second, maximising the plastics content mixed with cellulosic fractions. Therefore, the analysis financed by the project provided the first quantitative results of the potentialities of waste combustion for energy generation in Bolivia. By the analysis, it has been demonstrated that only the production of SRF from non-recyclable and non-hazardous MSW from the selective collection in Bolivia might provide about 2 billion MJ of energy in one year, accounting for more than one-tenth of the energy demand of the Bolivian cement industry. This amount of energy can increase if industrial waste and other waste fractions (i.e., used tyres, commercial waste) are also considered within the analysis. In addition, the co-processing of non-recyclable waste can solve part of the problem related to the MSW management system.

\subsubsection{Waste Based Briquettes}

The second laboratory test conducted within the project involves the evaluation of the briquettes' combustion behaviour in environmental conditions. The methods employed are the water boiling test and the emissions analysis laboratory tests. The first approach guarantees the evaluation of the performances of the fuel employed for cooking in terms of the time required for water boiling, the amount of biomass required for achieving the boiling temperatures, and its consumption per minute [27]. At the same time, the emissions related to the overall combustion of different fuels are compared. In particular, $\mathrm{CO}, \mathrm{PM}_{2.5}$, $\mathrm{CO}_{2}, \mathrm{SO}_{2}$, and $\mathrm{NO}$ are assessed, which are the most important parameters in terms of users' health [28]. The parameters are compared between $100 \%$ biomass-based briquettes (70\% wood straw and 30\% sawdust), 50\% sawdust and 50\% cellulosic briquettes, and 20\% sawdust and $80 \%$ cellulosic briquettes. Both materials (carboard and sawdust) are waste fractions currently disposed of in the sanitary landfill. Finally, a comparison with fuelwood is implemented. The aim is to demonstrate that waste-based briquettes can be alternative fuels that can be employed instead of wood in Andean rural areas.

Preliminary results report that biomass-based briquettes have a similar material consumption rate compared to fuelwood, while the emissions of $\mathrm{PM}_{2.5}$ are similar among the two different biofuels. The main differences are related to the boiling time and the emissions of $\mathrm{CO}_{2}$ and $\mathrm{CO}$. It seems that biomass-based briquettes produce less energy per minute compared to fuelwood, while carbon monoxide emissions are higher for biomass briquettes, and while $\mathrm{CO}_{2}$ emissions are higher for fuelwood. On the other hand, biomassbased briquettes are more efficient for heating using since the consumption per minute is considerably less than fuelwood, explaining why the time required for water boiling is higher. Promising results were obtained by adding cardboard waste to the biomass- 
based briquettes, reducing carbon emissions and improving the energy efficiency of the combustion process.

Future developments of the research are related to the analysis of cardboard-based briquettes, in parallel with an on-field analysis in rural areas where waste-based briquettes will be employed and the opinion of the local citizens assessed. In addition, an economic analysis of briquette production, transportation, and selling will be performed in order to provide a preliminary economic analysis to evaluate the sustainability of the approach. This analysis can be a tangible result, given by the LaPazRecicla project, to support a circular economy and the application of alternative fuels in rural areas of the Andean region.

\subsection{Social Inclusion: Recycling Campaigns, Seminars, and Technical Courses}

During the project, two recycling campaigns, four seminars, and three technical courses were organised. The campaigns involved the population and the participation of volunteers motivated to support selective collection and recycling policies. The first was an online campaign, while the second was hybridised, with some online activities and others in presence. More than 30 volunteers were involved, about 2000 people were interviewed, and 150 children were engaged with awareness games. Figure 6 reports some activities carried out in October 2021 during the public campaigns.

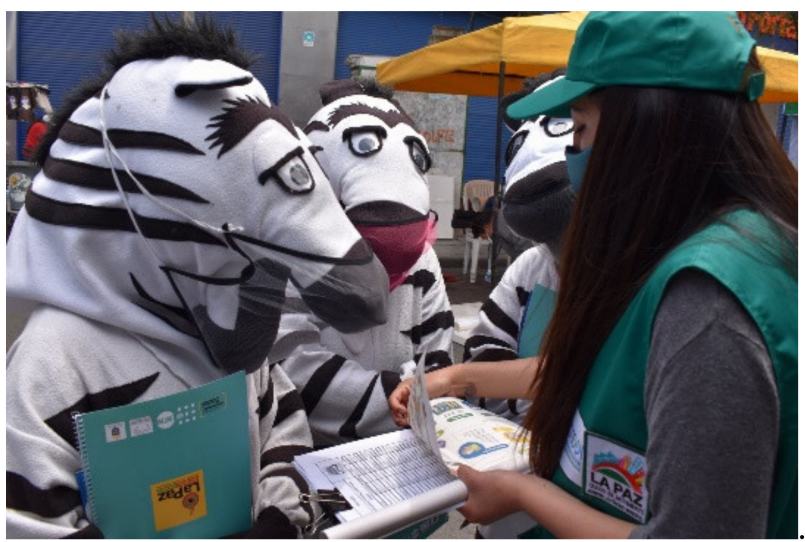

(a)

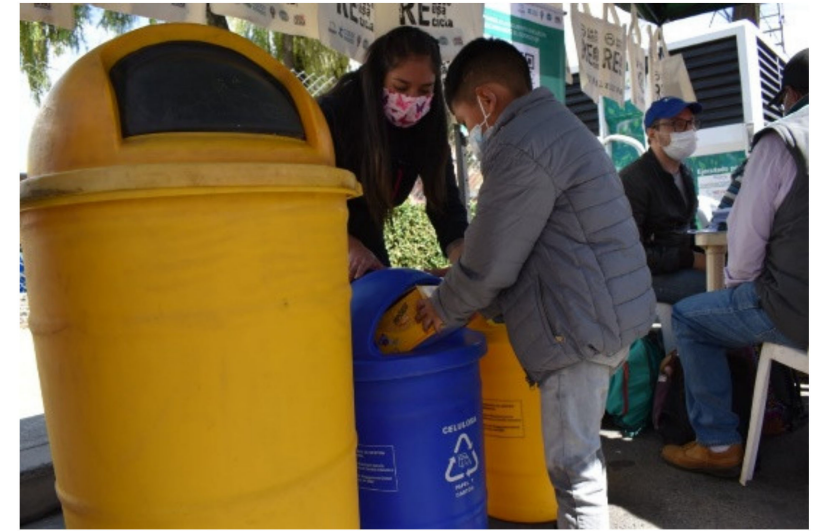

(b)

Figure 6. Recycling and selective collection campaigns implemented in La Paz: (a) questionnaire survey organised in the city in cooperation with the local "mascots" (zebras of La Paz); (b) educational plays organised for children.

During the period of the project, four seminars were organised: three online and one in presence, all related to the recycling and recovery of solid waste. More than 400 people participated, where technicians, citizens, students, stakeholders, and policy makers took part as an active audience. The topics explored by the seminars were related to the recycling of MSW, the recovery of non-recyclable waste, the implementation of CDW recycling actions, and the outputs of the LaPazRecicla project. Finally, three technical courses were organised, specifically for SWM practitioners from the public sector. In particular, the courses provided knowledge about the correct management of CDW, the challenges and opportunities related to waste-to-energy options, and the benefits related to the Circular Economy in developing regions. More than 150 participants were engaged. In the scientific literature, the involvement of the population, the improvement of technical knowledge, and the organisation of public campaigns, among other social and technical actions, are considered really important to implement appropriate SWM systems [29-32]. The project contributed to improving local awareness and technical knowledge in SWM, in parallel with the implementation of treatment plants, theoretical analyses, and laboratory tests. 


\subsection{Theoretical Analysis}

\subsubsection{LCA of the MSW and CDW Management System}

The LCA has been employed to estimate the potential environmental impacts generated by the CDW and MSW management system before and after the project. Regarding the formal MSW management system, the LCA has been focused on inorganic waste. Therefore, organic waste composting has not been involved in the analysis. Six environmental impact categories were assessed and a sensitivity analysis of ten parameters was implemented. In addition, the scenario assessment, in relation to the increase in the recycling rate, has been performed. The results of the first assessment suggest that the environmental impacts are mostly sensitive in relation to landfill gas collection efficiency, while global warming is the most variable impact category (341.38-551.95 $\mathrm{kg} \mathrm{CO}_{2}$-eq $\left.\mathrm{t}_{\mathrm{MSW}}\right)$. Finally, it has been estimated that by increasing MSW recycling from $235 \mathrm{t}$ to about $473 \mathrm{t}$ per year, human toxicity potential is reduced by about $18 \%$ and freshwater aquatic ecotoxicity by about $12 \%$, which represents the indicators that most benefit from MSW recycling [33].

The second analysis conducted was specifically related to the CDW mismanagement system. The implementation of a recycling system has been modelled within the LCA software. The assessment wants to quantify the benefits of inert CDW recycling in the function of the selective collection rate, and the distances from the CDW generation to the material recycling facility. The outcomes of the research suggest that increasing the selective collection rates (5\% to $99 \%$ ) spread the importance of transportation distances: transportation limits should be lower than about $40 \mathrm{~km}$ in order to make recycling beneficial for all environmental impacts for all selective collection rates. It represents the current situation since the current MRF has been located about 25-30 km away from the farthest point of generation [34].

Finally, a comparison between CDW and MSW has been conducted, with an overall analysis implemented for quantifying the environmental impacts that the SWM can generate. The outcomes of the analysis reported that, at a municipal level, CDW mismanagement contributes more than $60 \%$ to the freshwater aquatic ecotoxicity in the SWM system. On the other hand, recycling allows for the higher achievement of avoided impacts than the ones produced for three of six environmental impacts. Therefore, MSW and CDW recovery are important options for preventing environmental degradation [35]. By the analysis, it has been estimated that about 122,000 $\mathrm{t} \mathrm{CO}_{2}$-eq are generated by the system in one year. To provide an average carbon footprint, it can be estimated that a beech forest of northern Europe can remove about $1.5 \mathrm{t} \mathrm{CO}_{2}$ per year [36]. Therefore, it can be estimated that about 81,000 ha (about $800 \mathrm{~km}^{2}$ ) of green areas can be required to uptake the carbon emissions of the SWM of La Paz. The carbon footprint is reported in Figure 7, and it is compared to the area of La Paz. The comparison intends to compare the magnitude of the impact and it is not equivalent to the area that the municipality of La Paz should cover with trees.

\subsubsection{MFA of CDW Management Scenarios}

An MFA has been implemented to quantify the CDW potentially generated at the municipal level and the future recycling scenarios that can be implemented in La Paz. Secondary data were collected from the international literature and local documentation. The product between the constructed or demolished areas and the specific average waste generation rate gives the potential amount of CDW per waste fraction and generator. Three scenarios were considered, involving the implementation of a centralised block-making plant and the recovery of recyclable aggregates with mobile and centralised treatment systems.

By these results, the average annual costs for a reference scenario were assessed. The number of resources obtained from the processing of recyclable materials, as well as the amount of non-inert selected materials and hazardous waste or rejects that should be disposed of, were estimated. It was valued that more than about 270,000 $\mathrm{t}$ of CDW are potentially generated yearly in La Paz, about two-times more than the CDW projected by local authorities. By the scenarios analysis, it was always estimated that more than 
$60 \%$ of the inert aggregates can potentially be recycled, with a cost higher than about USD $8 \mathrm{t} \mathrm{CDW}^{-1}$, and lower than about USD $32 \mathrm{t} \mathrm{CDW}^{-1}$. The most attractive scenario involves the source separation of recyclable materials and the hybrid organisation of stationary and mobile recycling facilities. Therefore, the analysis allows supporting and justifying the implementation of CDW treatment plants.

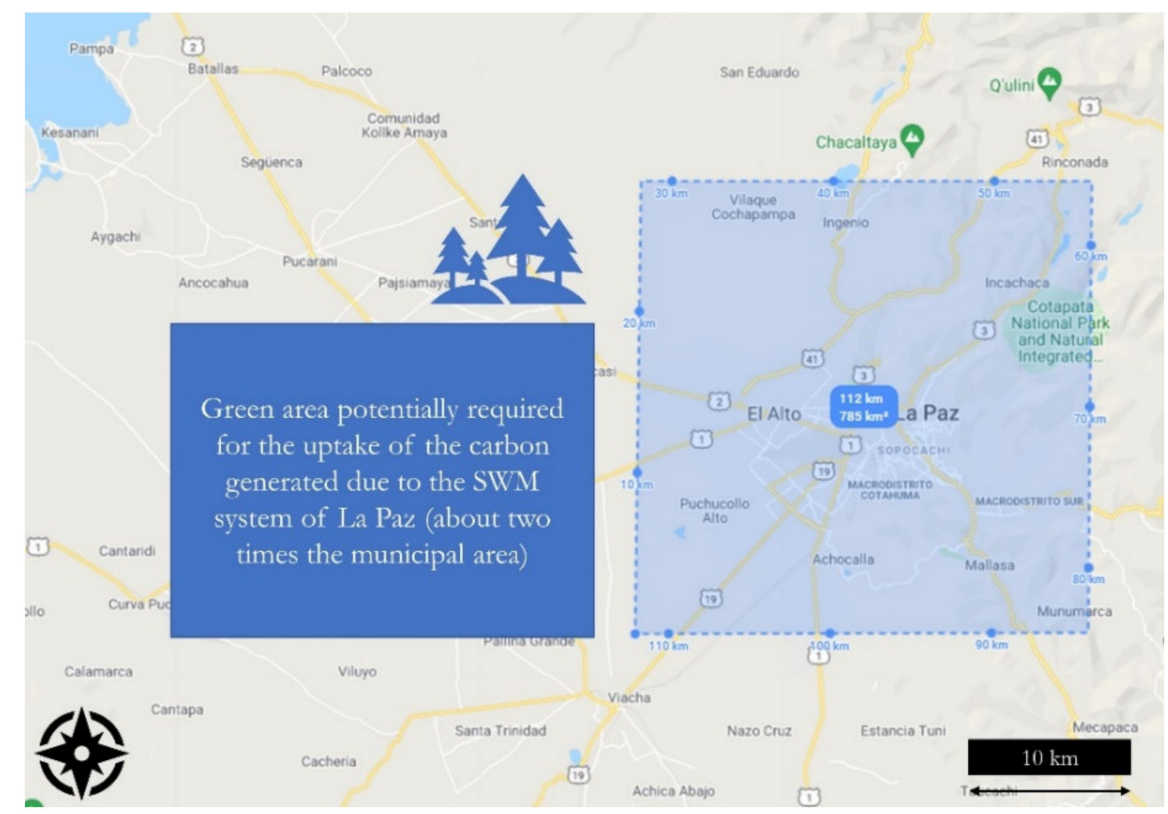

Figure 7. Potential carbon footprint related to the SWM system analysed in La Paz.

\subsubsection{Questionnaire Surveys}

A questionnaire survey has been implemented with online forms in 2020 during the COVID-19 pandemic. The forms were shared through social networks and messages, thanks to the support of students and volunteers. This study performed 998 household surveys in La Paz. The aim was to explore residents' waste recycling practices and their connection with waste collection services. The study involved a correlation analysis to assess the main factors that can influence the participation of local citizens to implement the selective collection at home.

Results reported that the citizens more active in recycling in La Paz are likely women, with an education level of either undergraduate or graduate, and with an age between 30 and 40 years or older than 50 years. In addition, important results were obtained in relation to the informal recycling system. It has been demonstrated that informal recyclers are responsible for providing an effective but separate collection system to the citizens of lower income levels: about $38 \%$ sell the sorted waste, deliver it to informal collectors, or leave it on the streets. People involved in the system consider it very useful to recycle the waste they generate. Furthermore, less than $5 \%$ of the participants think recycling is of little use.

The factor that most affects the implementation of recycling is not knowing to whom the waste can be delivered once classified, since about $22 \%$ of the respondents affirm that it affects them very much or a lot. The research provided important results that justify the implementation of selective collection system in La Paz. In 2021, a second survey was organised and more than 950 people were interviewed. Similarly, a third campaign will be organised in 2022 in order to collect other information, possibly through face-to-face interviews. 


\section{Discussion}

\subsection{Criticalities in Implementing Appropriate SWM Systems in Developing Countries}

The field of SWM needs people from various disciplines and competencies. SWM planning and operations involve interdisciplinary specialists and scientists, offering a wide range of intellectual and practical challenges [37]. This makes SWM difficult to implement in areas where know-how and integrated skills are not available. Five pillars for implementing integrated and sustainable SWM can be defined: public policies, legal aspects, public-private partnership, disposal techniques, and energy recovery options [38]. To these pillars, social inclusion, awareness, and education should also be added. However, environmental education is mostly lacking in developing countries, due to fragilities in practical environmental curricula that can respond to modern-day environmental issues [39].

Apart from the implementation of technological infrastructures, the organisation of public campaigns and the involvement of the population is, most of the time, challenging in low-income countries. Some authors suggested involving local communities in antilitter monitors' training initiatives, instead of traditional clean-up and/or education and awareness campaigns, which are considered to have short-lived impacts in metropolitan areas of developing countries [40]. In addition, policy alternatives to implement recycling actions are a landfill tax and rising council taxes. However, both are politically unfeasible [41]. Another legal tool that can improve SWM systems is the "extended producer responsibility". This strategy promotes the proper management of product packaging; however, poor source-separation, informal sector activities, exclusive focuses on economic aspects, and a lack of expertise and public awareness campaigns are always barriers that make the formal appropriate management and collection of recyclable waste unfeasible in developing countries [42].

The probability of municipalities' adoption of recycling programs in developing countries has shown slight increases in the last decade, but these is not enough for a substantial change towards a more sustainable SWM model. The gap between urban and rural municipalities, and the need to inject important funds into the system as a whole, are still big challenges [43]. At the same time, spirituality and religious aspects can affect daily disposal routines, as can frustration, due to a lack of perspectives [44].

On average, SWM in developing countries seems to be the challenge of the 21st century for moving towards a circular economy and sustainable development. Open dumps, gas emissions from open burning, marine littering, and a lack of energy and resources are only a few effects triggered by waste mismanagement [45]. High-income countries can figure as examples to start appropriate actions to support appropriate SWM systems. The implementation of international cooperative projects among interdisciplinary partners can provide support to achieve this goal [46]. The project LaPazRecicla, introduced in this paper, is another contribution.

\subsection{Considerations about the Actions: Is Political Instability a Failure Factor?}

The activities implemented within the project LaPazRecicla would support the implementation of recycling actions. To do so, both practical and theoretical approaches were implemented. The first was to give substantial support to the selective collection activities and the second was to add emphasis on the requirements to start planning future SWM actions. The positive results, as well as the encouraging impacts that can be achieved by the project, were underlined by the description of the research outcomes. However, an interesting point to be discussed is the challenge that the current system is facing and which can make the project a success or, on the other hand, an effort that does not instigate consistent future massive changes.

The political instability, the lack of local technical knowledge, and the absence of planning for a long-term period can affect the positive effects of the action. The construction of pilot plants can have positive future applications, such as the assessment of the market and the replicability of the treatment plants both on a small and large scale, depending on local requirements and financial availability. However, political will can be a big challenge 
since every four-to-five years the local municipal government changes and the vision of policy makers can be completely different. Will the systems implemented by the project be used in the future? Are the treatment plants within the current political plans? These are challenges that are out of the possible planning action implemented by the actors involved in LaPazRecicla since it does not depend on the quality of the actions or the treatment plant that was built. Political will is not always moved by rational and technical reason, but by the ideals of the people forming part the parties.

Social involvement can be also affected by a lack of planning, a logical consequence of the political instability, although the positive effect of this type of action has been widely discussed before. What if the future of the SWM is going to be radically changed? If the project implemented in 2019 does not meet the ideals of the politicians in charge in 2022, the message to the local population might change in terms of selective collection rules, recycling actions, and environmental efforts, among others. Can the campaigns provide effective changes in public behaviour and awareness if the political will shifts to other plans? In addition, the problem of a big city is related to the quantification of the results. The action involves about 3000 inhabitants in a city of about 950,000. How can behaviour changes be measured at the municipal level? Therefore, a lack of coherence in strategies' implementation and a lack of reliable outcomes related to population behaviour changes might affect the efforts in social inclusion and involvement, wasting time and efforts.

Similarly, laboratory analyses are of the utmost importance in order to spread knowledge among local researchers, professors, and technicians. However, the results, which can be published in the scientific literature and disseminated also at international level, cannot be understood, or can be "forgotten" by local decision makers. Who has the technical knowledge to read the results if local technicians changed due to the transformation of operators and office staff? Similarly, future research cannot be supported by the lack of local resources. Who can finance future research on a laboratory scale? Who can be interested in it if the political will has completely changed? The lack of internal financial resources also makes involvement in the research of trained operators and students very difficult. Who will implement similar research in the future if local universities have no financial resources to move towards future research actions? Therefore, if not properly managed, laboratory research and results might end in a no-future-applications approach that renders the action another waste of resources.

At the same time, LCA, scenarios analysis, and social surveys can be actions and studies that cannot be considered if local policy makers are not interested in them. This might happen due to the low interest of local politicians in environmental themes since the focus can be given only to economic factors. How can strategies that have been suggested by the LCA be effectively implemented at the local level? A 1-to-3-year-period plan cannot allow the introduction of recycling actions suggested by the LCA and scenarios analysis, considering that, in 5 years, MSW formal recycling rates will increase by less than 0.1 percentage points.

On average, this discussion underlined that political instability could affect the positive contribution of small-scale actions introduced by international cooperative projects that otherwise contribute only to positive and effective changes towards sustainable development, also because no other effective methods can be introduced in low-income countries to support the implementation of appropriate actions in the short term. In Table 2, the pros and cons of the actions implemented within the LaPazRecicla project are reported, underlining, therefore, the previous consideration in terms of opportunities and challenges related to the implementation of development projects in low-middle income countries such as Bolivia. 
Table 2. Pros and cons of the approaches implemented within the project and future developments.

\begin{tabular}{|c|c|c|c|}
\hline Method/Actions & Pros & Cons & Future Developments \\
\hline \multicolumn{4}{|c|}{ Practical Actions } \\
\hline Construction of pilot plants & $\begin{array}{l}\text { Improve the recyclability of } \\
\text { some MSW and CDW } \\
\text { fractions, evaluate the } \\
\text { economic affordability and the } \\
\text { market, improve local } \\
\text { knowledge and know-how. }\end{array}$ & $\begin{array}{l}\text { Challenges in collecting clean } \\
\text { waste, many breaks during } \\
\text { the operation due to incorrect } \\
\text { waste inflow or electric energy } \\
\text { instability, doubts in future } \\
\text { applications due to political } \\
\text { instability, challenges in } \\
\text { writing regulations to support } \\
\text { the action. }\end{array}$ & $\begin{array}{l}\text { Scalability of the } \\
\text { small-scale treatment plants, } \\
\text { further research and analysis } \\
\text { of the products, dissemination } \\
\text { of the actions among national } \\
\text { stakeholders. }\end{array}$ \\
\hline Social involvement & $\begin{array}{l}\text { Improve local awareness, } \\
\text { disseminate the actions, } \\
\text { involve local volunteers in } \\
\text { recycling action, produce } \\
\text { young leaders in recycling. }\end{array}$ & $\begin{array}{l}\text { Small scale of the actions, } \\
\text { limited number of people } \\
\text { involved, risk of different } \\
\text { policy implementations in } \\
\text { the future. }\end{array}$ & $\begin{array}{l}\text { Replication of the activities, } \\
\text { reporting the actions to local } \\
\text { policy makers, information } \\
\text { campaigns in local } \\
\text { mass media. }\end{array}$ \\
\hline Laboratory analysis & $\begin{array}{l}\text { Generation of onsite primary } \\
\text { data, improvement of local } \\
\text { knowledge, provision of } \\
\text { laboratory equipment to } \\
\text { implement laboratory tests. }\end{array}$ & $\begin{array}{l}\text { Local policy makers do not } \\
\text { always consider the results } \\
\text { obtained, difficulties in } \\
\text { implementing long term } \\
\text { research, challenges in } \\
\text { involving local } \\
\text { private companies. }\end{array}$ & $\begin{array}{l}\text { Replicability of the tests with } \\
\text { different feedstocks and waste } \\
\text { types, dissemination of the } \\
\text { results among } \\
\text { national stakeholders. }\end{array}$ \\
\hline
\end{tabular}

\section{Theoretical Analysis}

Measurement of the impacts avoided or reduced thanks to the project, estimation of the

Life cycle assessment-LCA

Scenario's analysis

Social surveys carbon footprint of the SWM

of La Paz, definition of reliable scenarios that can be implemented with future plans.
Difficulties in primary data collection, low political interest in environmental impact quantifications, lack of local knowledge for the correct interpretation of the results.
Dissemination of the results among municipal and national stakeholders, application of the results to compare the SWM before and after the action.

Presentation of the results to municipal and national stakeholders, comparison of the results with real-world analyses of the CDW treatment plant introduced.

Share the results with local stakeholders, use the results obtained to support recycling actions and selective collection campaigns, define the target group so as to produce new environmental leaders.

\subsection{Policy Implications and Future Developments}

The results obtained by the project can provide information to policy makers to start implementing appropriate and integrated SWM systems in developing cities. First, the main suggestion is to implement SWM planning with long-term strategies that are able to improve current waste recycling rates. Therefore, continuity in policy application should be somehow guaranteed, finding a balance between new proposals and the following of past actions conducted by political opponents. Second, considering the involvement of 
interdisciplinary actors from different national and international backgrounds is a key point. Local decision makers should find, consider, and accept international aids from the private sector, universities, NGOs, and governments in order to support actions towards a circular economy. Then, the introduction of appropriate taxes and tariffs must be afforded. This is challenging for politicians, since increasing municipal taxes is unpopular. However, it is the only way to start sustainable SWM systems with effective benefits. To do so, the construction of small-scale treatment plants can be an option to quantify the pros and cons of a technology or a treatment, assessing the feasibility of recycling actions considering different points of view. Similarly, small-scale selective collection systems can be another point to start effective changes. The LaPazRecicla project provided evidence about the importance of starting these mentioned policies and the same development project can provide starting points to future developments. On one hand, the action offers chances to understand the potentialities of the scalability of recycling plants that are somehow innovative for the context. At the same time, the project provided important results in terms of social involvement and technical knowledge, both potentially able to support the implementation of integrated and appropriated SWM systems.

On the other hand, the project highlights the main barriers that should be overcome before starting a circular approach to the management of MSW and CDW. For example, the lack of a market that is ready to absorb secondary raw materials, the importance of identifying specific regulations to support the actions, and the significance of involving waste generators in implementing recycling activities, are only a few recommendations and developments that the project gives to local stakeholders as lessons learned. These findings and recommendations can be adopted also in other international contexts that suffer from inappropriate SWM systems, as well as developing economies that are addressing the issue of environmental contamination due to waste mismanagement.

\subsection{Comments about the Outcomes and Limitations of the Study}

To sum up, during the project, both practical and theoretical actions were implemented to support solid waste recycling and recovery. One MRF for treating recyclable CDW and four machines for obtaining secondary raw materials were implemented. The three machines, located in the MSW sorting plant of La Paz, allow for the production of secondary raw materials from waste glass, paper, and plastics. In parallel, a densification machine can produce about $200 \mathrm{~kg}$ of biomass waste-based briquettes per day, which can be potentially employed as alternative fuels for cooking and heating in rural areas. The research does not introduce the direct practical consequences related to this action since the project is still under development and further actions are required. A similar assessment should be implemented in the next years in order to evaluate the effectiveness of the action.

Laboratory tests financed by the project provided the first quantitative results of the potentialities of SRF production from non-recyclable and non-hazardous MSW from the selective collection in Bolivia. In addition, the analysis of the briquettes' combustion behaviour in environmental conditions provides evidence about the potential higher performances of waste-based briquettes compared to fuelwood, suggesting that waste-based briquettes can be potential alternative fuels for Bolivian rural areas. The action is still in progress and there is not a concrete application of the briquettes in the Bolivian market. This represents another future analysis requiring implementation in order to quantify the reliability of the approach and to evaluate its sustainability.

Activities for involving the local population were organised. More than 30 volunteers were involved, about 2000 people were interviewed, around 150 children were educated, more than 400 people were engaged with online and in presence seminars, and 150 SWM practitioners were formed in technical courses. The limitation here is related to the proportion of the people involved compared to the number of inhabitants. The action is quite numerically limited, and more campaigns, seminars, and public actions should be organised in the future. 
Finally, various theoretical evaluations were implemented. By the LCA, it was estimated that about $800 \mathrm{~km}^{2}$ of green areas could be required to uptake the carbon emissions of the SWM of La Paz, while it has been estimated that doubling the recycling rate of MSW can reduce human toxicity by about $18 \%$ and freshwater aquatic ecotoxicity of about $12 \%$. Furthermore, by the scenarios analysis, it was estimated that more than $60 \%$ of the CDW inert aggregates can potentially be recycled, with a cost higher than about USD 8 per tonne of waste, but lower than about USD 32. Here, the lack of primary data gives the results low reliability. However, the presentation of the outcomes in a range of values reduces the result's uncertainty, while the collection of these findings represent the first attempt in Bolivia to estimate CDW flows and management costs, and to quantify the environmental impacts related to a SWM system.

Finally, it has been demonstrated that people involved in recycling are likely women who are 30 years old and with an education level, while the informal recycling sector is responsible for providing an effective, separate collection system to the citizens of lowerincome levels, since about $38 \%$ of the people interviewed sell the sorted waste or deliver it to informal collectors. As before, more analysis should be implemented in the future, involving citizens that are not interested in recycling. This represents another future development that local engineers and decision makers should consider.

\section{Conclusions}

This article presented a real-world project implemented in Bolivia from 2019 to 2022. The methods and actions applied were introduced in parallel with preliminary and final results. Positive effects were presented. The project considerably improved local knowledge and provided evidence about the potentialities of waste-to-energy options. In addition, innovative recycling systems were built, giving emphasis to the requirements for an appropriate SWM system for La Paz. The study demonstrated that research and case studies can provide effective ideas and examples to international cooperative operators, international lenders, SWM practitioners, and policy makers to start practical actions towards sustainable development.

The project provided positive and interdisciplinary results (economic, social, and environmental) that can be of interest to international SWM practitioners. However, political will and continuity in action were underlined as important factors to have effective contributions, thanks to the project. The case study is novel both in terms of technical results and methodologies, since the project, LaPazRecicla, can have a new and effective influence to move towards a circular economy in developing countries. The authors recommend considering local political changes and issues in development projects in order to make the action more effective and to improve sustainability.

In conclusion, the research suggests moving to specific future research activities such as the introduction of cost analysis in CDW management, social behaviour in formal and informal recycling, scalability of small-scale treatment plants, identification of primary data in inventory analysis of an LCA, application of waste-based briquettes in rural areas, and SRF in cement kilns of developing countries. The project "LaPazRecicla: Towards a Circular Economy Model" can be considered one reliable and effective contribution to be replicated in developing areas, in order to move towards sustainable development while considering local issues, employing integrated approaches, and involving interdisciplinary actors.

Author Contributions: Conceptualisation, N.F.; Data curation, N.F. and I.J.C.M.; Formal analysis, N.F. and I.J.C.M.; Funding acquisition, R.P.; Investigation, N.F., I.J.C.M., and M.A.G.P.; Methodology, N.F.; Project administration, R.P., D.V.V., and E.G.G.L.; Resources, R.P. and D.V.V.; Software, N.F.; Supervision, E.G.G.L., M.A.G.P., F.C. and V.T.; Validation, F.C. and V.T.; Visualisation, N.F.; Writingoriginal draft, N.F.; Writing-review and editing, N.F. All authors have read and agreed to the published version of the manuscript. 
Funding: This research was funded by the Italian Agency for Development Cooperation, grant number AID 011908. Its contents are the sole responsibility of the authors and do not necessarily reflect the views of the Agency.

Institutional Review Board Statement: Not applicable.

Informed Consent Statement: Not applicable.

Data Availability Statement: The data presented in this study are available on request from the corresponding author.

Acknowledgments: The authors thank the Municipal Secretary of Environmental Management of the Autonomous Municipal Government of La Paz, the Major University of San Andrés-Faculty of Engineering and the Italian non-governmental organisation COOPI, and the La Paz field office, for their cooperation in implementing the research within the framework of the project "LaPazRecicla. Integrated approach to the waste management in Bolivia: development of new technologies to foster circular economy in the municipality of La Paz", led by COOPI.

Conflicts of Interest: The authors declare no conflict of interest.

\section{References}

1. Olay-Romero, E.; Turcott-Cervantes, D.E.; Hernández-Berriel, M.d.C.; Lobo-García de Cortázar, A.; Cuartas-Hernández, M.; de la Rosa-Gómez, I. Technical indicators to improve municipal solid waste management in developing countries: A case in Mexico. Waste Manag. 2020, 107, 201-210. [CrossRef] [PubMed]

2. Mama, C.N.; Nnaji, C.C.; Nnam, J.P.; Opata, O.C. Environmental burden of unprocessed solid waste handling in Enugu State, Nigeria. Environ. Sci. Pollut. Res. 2021, 28, 19439-19457. [CrossRef]

3. Maalouf, A.; Mavropoulos, A.; El-Fadel, M. Global municipal solid waste infrastructure: Delivery and forecast of uncontrolled disposal. Waste Manag. Res. 2020, 38, 1028-1036. [CrossRef]

4. Aleluia, J.; Ferrão, P. Characterization of urban waste management practices in developing Asian countries: A new analytical framework based on waste characteristics and urban dimension. Waste Manag. 2016, 58, 415-429. [CrossRef] [PubMed]

5. Carlos-Alberola, M.; Izquierdo, A.G.; Colomer-Mendoza, F.J.; Barreda-Albert, E. Design of a municipal solidwaste collection system in situations with a lack of resources: Nikki (Benin), A case in Africa. Sustainability 2021, 13, 1785. [CrossRef]

6. Vujić, G.; Gonzalez-Roof, A.; Stanisavljević, N.; Ragossnig, A.M. Municipal solid waste development phases: Evidence from EU27. Waste Manag. Res. 2015, 33, 1112-1120. [CrossRef] [PubMed]

7. Nwachukwu, M.A.; Ronald, M.; Feng, H. Global capacity, potentials and trends of solid waste research and management. Waste Manag. Res. 2017, 35, 923-934. [CrossRef]

8. Tan, X.; Zhu, K.; Meng, X.; Gu, B.; Wang, Y.; Meng, F.; Liu, G.; Tu, T.; Li, H. Research on the status and priority needs of developing countries to address climate change. J. Clean. Prod. 2021, 289, 125669. [CrossRef]

9. Ferronato, N.; Gorritty Portillo, M.A.; Guisbert Lizarazu, E.G.; Torretta, V. Application of a life cycle assessment for assessing municipal solid waste management systems in Bolivia in an international cooperative framework. Waste Manag. Res. 2020, 38, 98-116. [CrossRef]

10. Ikhlayel, M.; Nguyen, L.H. Integrated Approaches to Water Resource and Solid Waste Management for Sustainable Development. Sustain. Dev. 2017, 25, 467-481. [CrossRef]

11. Murase, N.; Murayama, T.; Nishikizawa, S.; Sato, Y. Quantitative analysis of impact of awareness-raising activities on organic solid waste separation behaviour in Balikpapan City, Indonesia. Waste Manag. Res. 2017, 35, 1013-1022. [CrossRef] [PubMed]

12. Gibellini, S.; Abu Qdais, H.; Vaccari, M. Municipal solid waste management in refugee hosting communities: Analysis of a case study in northern Jordan. Waste Manag. Res. 2021, 40. [CrossRef] [PubMed]

13. Olley, J.E.; Ijgosse, J.; Rudin, V.; Alabaster, G. Developing a common framework for integrated solid waste management advances in Managua, Nicaragua. Waste Manag. Res. 2014, 32, 822-833. [CrossRef]

14. Huh, T.; Kim, H.J. Korean experimentation of knowledge and technology transfer to address climate change in developing countries. Sustainability 2018, 10, 1263. [CrossRef]

15. Salmenperä, H.; Pitkänen, K.; Kautto, P.; Saikku, L. Critical factors for enhancing the circular economy in waste management. J. Clean. Prod. 2021, 280, 124339. [CrossRef]

16. Godfrey, L.; Muswema, A.; Strydom, W.; Mamafa, T.; Mapako, M. Co-operatives as a development mechanism to support job creation and sustainable waste management in South Africa. Sustain. Sci. 2017, 12, 799-812. [CrossRef]

17. Moh, Y.C.; Abd Manaf, L. Solid waste management transformation and future challenges of source separation and recycling practice in Malaysia. Resour. Conserv. Recy. 2017, 116, 1-14. [CrossRef]

18. Ferronato, N. Integrated analysis for supporting solid waste management development projects in low to middle income countries: The NAVA-CE approach. Environ. Dev. 2021, 39, 100643. [CrossRef] 
19. Ferronato, N.; Gorritty Portillo, M.A.; Guisbert Lizarazu, E.G.; Torretta, V.; Bezzi, M.; Ragazzi, M. The municipal solid waste management of La Paz (Bolivia): Challenges and opportunities for a sustainable development. Waste Manag. Res. 2018, 36, 288-299. [CrossRef]

20. Ferronato, N.; Portillo, M.A.G.; Lizarazu, G.E.G.; Torretta, V. Formal and informal waste selective collection in developing megacities: Analysis of residents' involvement in Bolivia. Waste Manag. Res. 2020, 39, 108-121. [CrossRef]

21. Pierini, V.I.; Mazzeo, N.; Cazenave, M.; Semmartin, M. Waste generation and pro-environmental behaviors at household level: A citizen science study in Buenos Aires (Argentina). Resour. Conserv. Recy. 2021, 170, 105560. [CrossRef]

22. Khair, H.; Rachman, I.; Matsumoto, T. Analyzing household waste generation and its composition to expand the solid waste bank program in Indonesia: A case study of Medan City. J. Mater. Cycles Waste 2019, 21, 1027-1037. [CrossRef]

23. Manowong, E. Investigating factors influencing construction waste management efforts in developing countries: An experience from Thailand. Waste Manag. Res. 2012, 30, 56-71. [CrossRef] [PubMed]

24. Rondinel-Oviedo, D.R. Construction and demolition waste management in developing countries: A diagnosis from 265 construction sites in the Lima Metropolitan Area. Int. J. Constr. Manag. 2021. [CrossRef]

25. Fajfrlíková, P.; Brunerová, A.; Roubík, H. Analyses of waste treatment in rural areas of east java with the possibility of low-pressure briquetting press application. Sustainability 2020, 12, 8153. [CrossRef]

26. Brunerová, A.; Roubík, H.; Brožek, M.; Van Dung, D.; Phung, L.D.; Hasanudin, U.; Iryani, D.A.; Herák, D. Briquetting of sugarcane bagasse as a proper waste management technology in Vietnam. Waste Manag. Res. 2020, 38, 1239-1250. [CrossRef]

27. Quist, C.M.; Jones, M.R.; Lewis, R.S. Influence of variability in testing parameters on cookstove performance metrics based on the water boiling test. Energy Sustain. Dev. 2020, 58, 112-118. [CrossRef]

28. Salthammer, T.; Schripp, T.; Wientzek, S.; Wensing, M. Impact of operating wood-burning fireplace ovens on indoor air quality. Chemosphere 2014, 103, 205-211. [CrossRef]

29. López de Munain, D.; Castelo, B.; Ruggerio, C.A. Social metabolism and material flow analysis applied to waste management: A study case of Autonomous City of Buenos Aires, Argentina. Waste Manag. 2021, 126, 843-852. [CrossRef]

30. Bortoleto, A.P.; Hanaki, K. Report: Citizen participation as a part of integrated solid waste management: Porto Alegre case. Waste Manag. Res. 2007, 25, 276-282. [CrossRef]

31. Liao, C.; Li, H. Environmental education, knowledge, and high school students' intention toward separation of solid waste on campus. Int. J. Env. Res. Pub. Health 2019, 16, 1659. [CrossRef] [PubMed]

32. Ferronato, N.; Guisbert Lizarazu, E.G.; Velasco Tudela, J.M.; Blanco Callisaya, J.K.; Preziosi, L.; Torretta, V. Selective collection of recyclable waste in Universities of low-middle income countries: Lessons learned in Bolivia. Waste Manag. 2020, 105, 198-210. [CrossRef] [PubMed]

33. Ferronato, N.; Moresco, L.; Guisbert Lizarazu, G.E.; Gorritty Portillo, M.A.; Conti, F.; Torretta, V. Sensitivity analysis and improvements of the recycling rate in municipal solid waste life cycle assessment: Focus on a Latin American developing context. Waste Manag. 2021, 128, 1-15. [CrossRef] [PubMed]

34. Ferronato, N.; Guisbert Lizarazu, G.E.; Gorritty Portillo, M.A.; Moresco, L.; Conti, F.; Torretta, V. Environmental assessment of construction and demolition waste recycling in Bolivia: Focus on transportation distances and selective collection rates. Waste Manag. Res. J. A Sustain. Circ. Econ. 2021. [CrossRef] [PubMed]

35. Ferronato, N.; Moresco, L.; Guisbert Lizarazu, G.E.; Gorritty Portillo, M.A.; Conti, F.; Torretta, V. Comparison of environmental impacts related to municipal solid waste and construction and demolition waste management and recycling in a Latin American developing city. Environ. Sci. Pollut. Res. 2021; in press. [CrossRef] [PubMed]

36. Pilegaard, K.; Ibrom, A.; Courtney, M.S.; Hummelshøj, P.; Jensen, N.O. Increasing net CO2 uptake by a Danish beech forest during the period from 1996 to 2009. Agric. For. Meteorol. 2011, 151, 934-946. [CrossRef]

37. Un-Habitat. Solid Waste Management in the World's Cities; Un-habitat: Nairobi, Kenya, 2010.

38. Batista, M.; Goyannes Gusmão Caiado, R.; Gonçalves Quelhas, O.L.; Brito Alves Lima, G.; Leal Filho, W.; Rocha Yparraguirre, I.T. A framework for sustainable and integrated municipal solid waste management: Barriers and critical factors to developing countries. J. Clean. Prod. 2021, 312, 127516. [CrossRef]

39. Debrah, J.K.; Vidal, D.G.; Dinis, M.A.P. Raising awareness on solid waste management through formal education for sustainability: A developing countries evidence review. Recycling 2021, 6, 6. [CrossRef]

40. Zambezi, F.M.; Muisa-Zikali, N.; Utete, B. Effectiveness of community participation as anti-litter monitors in solid waste management in metropolitan areas in a developing country. Environ. Dev. Sustain. 2021, 23, 747-764. [CrossRef]

41. Valenzuela-Levi, N.; Araya-Córdova, P.J.; Dávila, S.; Vásquez, Ó.C. Promoting adoption of recycling by municipalities in developing countries: Increasing or redistributing existing resources? Resour. Conserv. Recy. 2021, 164, 105173. [CrossRef]

42. Jalalipour, H.; Ahmadi, M.; Jaafarzadeh, N.; Morscheck, G.; Narra, S.; Nelles, M. Provision of extended producer responsibility system for products packaging: A case study of Iran. Waste Manag. Res. 2021, 39, 1291-1301. [CrossRef] [PubMed]

43. Araya-Córdova, P.J.; Dávila, S.; Valenzuela-Levi, N.; Vásquez, Ó.C. Income inequality and efficient resources allocation policy for the adoption of a recycling program by municipalities in developing countries: The case of Chile. J. Clean. Prod. 2021, $309,127305$. [CrossRef]

44. Raab, K.; Salem, M.; Wagner, R. Antecedents of daily disposal routines in the Gaza Strip refugee camps. Resour. Conserv. Recy. 2021, 168, 105427. [CrossRef] 
45. Ferronato, N.; Torretta, V. Waste mismanagement in developing countries: A review of global issues. Int. J. Env. Res. Pub. Health 2019, 16, 1060. [CrossRef] [PubMed]

46. Agamuthu, P.; Hansen, J.A. Universities in capacity building in sustainable development: Focus on solid waste management and technology. Waste Manag. Res. 2007, 25, 241-246. [CrossRef] [PubMed] 